\title{
PELAKSANAAN HAK MUTLAK AHLI WARIS TERHADAP SURAT WASIAT/TESTAMEN YANG MENYIMPANG DARI KETENTUAN LEGITIEME PORTIE BURGERLIJK WETBOEK (BW)
} Anastassia Tamara Tandey, Ignasius Christian Sompie, Chrispinus Zina, Novalita Eka Christy Pihang

Universitas Airlangga

Email: tassya1997.tassya@gmail.com

Abstrak

Kematian seseorang yang meninggalkan harta warisannya diatur dengan hukum waris. Pengaturan dengan hukum waris ini, berguna untuk melindungi para pihak seperti ahli waris sehingga tidak terjadi sengketa atas harta peninggalan pewaris. Ahli waris, terdapat dua jenis, diantaranya ahli waris berdasarkan surat wasiat dan ahli waris berdasarkan ketentuan perundangundangan. Untuk pembagian warisan yang berdasarkan surat wasiat terdapat pengaturannya, dikarenakan secara faktual orang yang meninggalkan surat wasiat dimana pembagiannya ahli waris yang berhak mendapatkan bagian warisan lebih sedikit dibandingkan ahli waris diluar yang mendapatkan warisan. Untuk melindungi penerima warisan dari surat wasiat yang terdapat penyimpangan diatur dengan legitieme portie atau bagian mutlak harus diterima ahli waris yang seharusnya berhak menerima warisan.

Kata Kunci: Ahli Waris, Testamen, Legitieme Portie

\begin{abstract}
The death of someone who left his inheritance regulated by inheritance law. Arrangement with inheritance law is useful to protect parties such as heirs so that there is no dispute over the assets left by the heirs (people who leave property). Heirs, there are 2 (two) types, namely heirs based on a will and heirs based on statutory provisions. For the distribution of inheritance based on a will there is a regulation, because in fact the heir can make a will that the distribution of heirs who are entitled to inheritance gets less than the heirs who are outside entitled to inheritance. To protect the heirs who are entitled to inherit from a will with a deviation set with legitieme portie or a absolute part that must be accepted by the heirs who should be entitled to inherit
\end{abstract}

Keywords: Heirs, Testament, Legitieme Portie 


\section{PENDAHULUAN}

ematian seseorang dapat membawa akibat hukum, yaitu dimulai dari
dirinya maupun sesamanya. Kematian tersebut berpengaruh terhadap
harta kekayaan yang ditinggalkan semasa hidupnya. Dan untuk
pengaturan mengenai harta kekayaan peninggalan ini dalam hukum
telah diatur pembagiannya, pengurusannya dan lain sebagainya sehingga apabila terjadi sengketa terdapat jalan keluar untuk menyelesaikan masalah ini. Harta kekayaan yang ditinggalkan ini dikenal dengan sebutan warisan. Pengaturan mengenai warisan ini diatur menggunakan hukum waris, tetapi terdapat istilah lain juga yang digunakan dalam pengaturan warisan ini seperti hukum pewarisan, hukum kewarisan, ada juga seperti yang disebutkan sebelumnya yaitu hukum waris. Pada hakekatnya istilah-istilah yang digunakan dari sisi pengertian, penggunaan istilah tersebut bukan menjadi sebuah masalah melainkan memilki tujuan yang sama sebagai jalan keluar bagi masalah-masalah yang kerap terjadi dalam lingkup dunia terlebih di Indonesia dalam hal ini mengenai masalah pewarisan. Hukum waris di Indonesia dibedakan menjadi tiga sistem hukum waris, ini dikarenakan pengaruh dari masa penjajahan di Indonesia yang mengakibat penggolongan penduduk dan hukum yang digunakan sebagaimana diatur dalam Pasal 131 jo. 163 I.S, Staatsblad 1917 Nomor 129, Staatsblad 1924 Nomor 557 tentang Penundukan Diri terhadap Hukum Eropa, yaitu sebagai berikut: (1) Hukum Waris Burgerlijk Wetboek (yang selanjutnya disebut BW); (2) Hukum Waris Islam; dan (3) Hukum Waris adat.

Hukum Waris BW diatur dalam Buku II Bab XII hingga Bab XVIII BW, yang diterapkan bagi Golongan Eropa termasuk golongan Timur Asing Tionghoa dan golongan yang mengikuti hukum Eropa. Hukum Waris Islam diatur berdasarkan INPRES No. 1 Tahun 1991 tentang Kompilasi Hukum Islam (selanjutnya cukup disingkat KHI) yang diterapkan bagi WNI yang beragama Islam, sebagaimana terdapat dalam Yurisprudensi MA No. 172K/SIP/1974. Hukum Waris Adat, diterapkan untuk golongan Bumi Putera yang patuh pada Hukum Adat dimana mempunyai sifat kekeluargaan, antara lain: sifat keibuan (Matrilineal), sifat kebapakan (Patrilineal) maupun campuran (Bilateral). Ketiga jenis sistem ini mempunyai ciri khas tersendiri yang menjadi pembeda antara yang satu dengan lainnya. ${ }^{1}$ Berbicara permasalahan warisan tidak terlepas dari tiga unsur pokok yang bersifat komulatif, diantaranya Pewaris (Erflater) adalah

${ }^{1}$ Sri Hajati, [ et.,al.], Hukum Waris Adat, Islam dan Burgerlijk Wetboek (Airlangga University Press 2018). [206]. 
orang yang meninggal dunia serta meninggalkan harta kekayaannya pada orang lain; Ahli waris (Erfgenaam) adalah orang yang berhak atas harta kekayaan yang ditinggalkan oleh pewaris; dan Harta warisan (Nalatenschap) atau disebut warisan adalah harta kekayaan yang ditinggalkan oleh orang yang meninggal dunia berupa segala harta kekayaan dari orang yang meninggal dunia. ${ }^{2}$

Berwasiat dalam hukum islam merupakan sunnah muakkad bagi setiap umat muslim, dikhususkan bagi seorang yang sakit keras atau nampak sebelum ajal menjemput. ${ }^{3}$ Ketentuan pengeluaran wasiat adalah firman Allah termuat didalam Al-Quran Surat Al Baqarah ayat 180 yang artinya: ${ }^{4}$

"Diwajibkan atas kamu apabila seorang di antara kamu kedatangan (tandatanda) maut, jika ia meninggalkan harta banyak, berwasiat untuk ibu-bapak dan karib kerabatnya secara ma'ruf, (ini adalah) kewajiban atas orangorang yang bertakwa."

Surat An-Nisaa' ayat 11:

Allah mensyariatkan bagimu tentang (pembagian pusaka untuk) anakanakmu. Yaitu bagian seorang anak lelaki sama dengan bagian dua orang anak perempuan [bagian laki-laki dua kali bagian perempuan adalah karena kewajiban laki-laki lebih berat dari perempuan, seperti kewajiban membayar maskawin dan memberi nafkah]; dan jika anak itu semuanya perempuan lebih dari dua [lebih daru dua maksudnya; dua atau lebih sesuai dengan yang diamalkan Nabi], maka bagi mereka dua pertiga dari harta yang ditinggalkan; jika anak perempuan itu seorang saja, maka ia memperoleh separuh harta. Dan untuk dua orang ibu-bapak, bagi masing-masingnya seperenam dari harta yang ditinggalkan, jika yang meninggal itu mempunyai anak; jika orang yang meninggal tidak mempunyai anak dan ia diwarisi oleh ibu bapaknya (saja), maka ibunya mendapat sepertiga; jika yang meninggal itu mempunyai beberapa saudara, maka ibunya mendapat seperenam. (Pembagian-pembagian tersebut di atas) sesudah dipenuhi wasiat yang ia buat atau (dan) sesudah dibayar utangnya. (Tentang) orang tuamu dan anakanakmu kamu tidak mengetahui siapa di antara mereka yang lebih dekat (banyak) manfaatnya bagimu. Ini adalah ketetapan dari Allah. Sesungguhnya Allah Maha Mengetahui lagi Maha Bijaksana.

${ }^{2}$ Sri Hajati, [ et.,al.], Hukum Waris Adat, Islam dan Burgerlijk Wetboek (Airlangga University Press 2018). 206-207].

${ }^{3}$ Sri Hajati, [ et.,al. ], Hukum Waris Adat, Islam dan Burgerlijk Wetboek (Airlangga University Press 2018).[138].

${ }^{4}$ H. Moh., Hukum Kewarisan Islam Sebagai Pembaruan Hukum Positif di Indonesia, (Sinar Grafika 2009).[55-56]. 
Apabila sebelum meninggal dunia dan seseorang telah meninggalkan wasiat, maka wasiat tersebut harus dijalankan dari harta peninggalannya dengan tidak melebihi dari satu per tiga harta bila dia mempunyai ahli waris dan jika dia akan berwasiat lebih dari satu per tiga, harus seizin penerima warisan. ${ }^{5}$ Berdasarkan KHI bentuk dari wasiat dapat dilakukan secara lisan dihadapan dua orang sebagai saksi atau dalam bentuk tertulis yang dilakukan dihadapan dua orang sebagai saksi maupun dihadapan Notaris (Pasal 195 KHI). Konsep KHI tidak mewajibkan untuk membuat wasiat dalam bentuk tertulis atau menggunakan campur tangan Notaris, hal ini disesuaikan dengan keinginan si pembuat wasiat. Sedangkan didalam BW terkait dengan bentuk wasiat, Pasal 931 BW menjelaskan bahwa surat wasiat hanya dapat dibuat dengan, akta olografis, akta umum atau dengan akta tertutup. Berdasarkan beberapa ketentuan BW secara formil diatas surat wasiat wajib secara tertulis pembuatannya dihadapan Notaris ataupun dititipkan untuk disimpan oleh Notaris. ${ }^{6}$

Jika dibandingkan dengan BW yang mengatur bagian dari setiap ahli waris yang telah diatur oleh UU tidak dapat disimpangi, dengan memberikan warisan kepada penerima warisan dalam hal ini tidak berhak menerima harta warisan melebihi bagian penerima warisan yang berhak menerima harta warisan. Keadaan ini dikenal sebagai bagian mutlak (legitieme portie). Berbeda didalam hukum waris islam tidak ada pengaturan secara khusus, dimana hanya ditetapkan warisan tidak boleh melebihi satu per tiga dari harta kekayaan jika ingin diberikan lebih diijinkan, tetapi harus dibutuhkan persetujuan ahli waris sebagaimana telah diatur dalam Al-Quran ataupun KHI.

Adapula bentuk hukum waris yang ketiga yaitu waris menurut adat. Hukum waris adat tidak mengatur tentang adanya legitieme portie seperti yang tertuang didalam BW, seperti batasan yang ada dalam hukum waris islam yaitu bagiannya satu per tiga harta kekayaan pemberi warisan. Esensi dari hukum waris adat adalah merupakan proses penerusan, peralihan/pengoperan harta. Sesungguhnya proses dalam hal peralihan dapat dimulai sejak pemilik dari harta kekayaan itu sendiri masih hidup dan prosesnya terus berjalan hingga keturunannya masingmasing membentuk keluarga baru yang mandiri \{mentas dan mencar (Jawa)\} yang nanti pada waktunya tiba mendapat giliran untuk meneruskan prosesnya

${ }^{5}$ Moh. Muhibbin dan Abdul Wahid.Loc.Cit.

${ }^{6}$ Adam Lukmanto dan Munsharif Abdul Chalim, 'Tinjauan Hukum dan Akibatnya Terhadap Wasiat Tanpa Akta Notaris ditinjau dari Komplikasi Hukum Islam dan Kitab UndangUndang Hukum Perdata' (2017) 4 Jurnal Akta.[30-31]. 
kepada keturunan selanjutnya. "Proses tersebut tidak menjadi "akuut" apabila orang tua meninggal dunia. ${ }^{7}$ Tulisan ini dibuat, berfokus pada pembahasan mengenai surat wasiat/testamen sebagai ketentuan pelaksana dari keinginan pewaris. Dalam hal ini dimana si pewaris berhak sepenuhnya atas harta warisannya, yang oleh karena itu juga si pewaris berhak membagi harta kekayaannya kepada para ahli waris sesuai dengan kehendaknya. Hal ini akan tinjau menurut Hukum Waris BW sehingga isu yang diangkat dalam pembahasan ini adalah Pelaksanaan Hak Mutlak Ahli Waris Terhadap Surat Wasiat/Testamen yang Menyimpang Dari Ketentuan Legitieme Portie Burgerlijk Wetboek (BW).

\section{PEMBAHASAN}

\section{A. Pelaksanaan Hak Mutlak Ahli Waris Terhadap Surat Wasiat/Testamen yang Menyimpang Dari Ketentuan Legitieme Portie Burgerlijk Wetboek (BW).}

Wasiat kerap kali terjadi dalam lingkup kehidupan, dimana wasiat ini merupakan suatu perbuatan/perintah dari pewaris untuk terlaksananya suatu kehendak dari pewaris tersebut. Wasiat ialah pernyataan keinginan seseorang terhadap apa yang ingin ia lakukan terhadap harta kekayaannya setelah ia meninggal dunia. ${ }^{8}$ Dalam BW tidaklah diatur secara jelas mengenai pengertian dari pada wasiat itu sendiri, secara umum menurut Pasal 874 BW, wasiat merupakan segala harta seseorang yang meniggal dunia, adalah kepunyaan sekalian ahli warisnya menurut undang-undang, sekedar terhadap itu dengan surat wasiat tidak telah diambilnya suatu ketetapan yang sah. Dalam sistem hukum hukum waris di Indonesia terdapat pembatasan atas warisan yaitu: (1) Seseorang yang meninggalkan warisan (erflater) pada saat orang tersebut meniggal dunia; (2) Seseorang atau beberapa orang ahli waris (erfenaam) yang mempunyai hak menerima kekayaan yang ditinggalkannya itu; dan (3) Harta warisan (nalaten schap) yaitu wujud kekayaan yang ditinggalkan dan selalu beralih pada ahli waris tersebut. ${ }^{9}$

${ }^{7}$ Soerojo Wignjodipoero, Pengantar dan Asas-asas Hukum Adat, (PT. Toko Gunung Agung 1995).[161-162].

${ }^{8}$ Eman Suparman, Hukum Waris Indonesia dalam Perspektif Islam, Adat, BW, (Refika Aditama 2007).[95].

${ }^{9}$ Oemar Salim, Dasar-Dasar Hukum Waris Di Indonesia, (PT. Rineka Cipta 2000). [4]. 
Hukum waris dalam Perdata Barat dikenal juga dengan istilah erfrecht. Hukum waris menurut BW diatur dalam Pasal 830 BW sampai dengan Pasal 1130. Hukum waris juga diatur di dalam Instruksi Presiden Nomor 1 Tahun 1991 tentang Kompilasi Hukum Islam. Di Indonesia juga berlaku ketentuan waris adat yang sifatnya berupa hukum tidak tertulis. ${ }^{10}$ Pewarisan yang dibagi dalam 2 (dua) macam yaitu warisan yang didapat dari surat wasiat (testament) dan warisan yang didapat telah ditentukan oleh Undang-Undang ( $a b$ intestato). Pewarisan melalui surat wasiat (testament) adalah para ahli waris yang mendapatkan warisan didasarkan oleh keingingan pewaris, baik mencakup orang yang mendapat warisan atau yang dikenal dengan ahli waris ataupun bagian-bagian yang didapat oleh ahli waris. BW memberikan definisi mengenai surat wasiat atau testament pada Pasal 875 BW, yaitu:

"Ada pun yang dinamakan surat wasiat atau testamen ialah adalah suatu akta yang memuat pernyataan seorang tentang apa yang dikehendakinya akan terjadi setelah ia meninggal dunia, dan yang olehnya dapat dicabut kembali lagi."

Jadi, pewaris boleh saja membuat suatu wasiat atau memberikan hibah wasiat kepada seseorang, namun demikian pemberian tersebut tidak boleh melanggar hak mutlak (yang harus dimiliki) dari ahli waris yang berhak menrima warisan berdasarkan ketentuan perundang-undangan. Ketetapan dengan surat wasiat dalam Pasal 876 BW, terdiri dari 2 (dua) cara yaitu: ${ }^{11}$ (1) Dengan alas hak umum (Erfstelling), yaitu memberikan wasiat dengan tidak ditentukan bendanya secara tertentu; (2) Dengan alas hak khusus (Legaat), yaitu memberikan wasiat yang bendanya dapat ditentukan. Dalam BW mengenal 3 macam bentuk surat wasiat, yaitu: (1) Surat Wasiat Olografis:

Merupakan surat wasiat yang sepenuhnya ditulis dengan tangan dan ditanda-tangani oleh pewaris sendiri. Selanjutnya surat wasiat tersebut harus diserahkan untuk disimpan pada pejabat yang berwenang dalam hal ini seorang notaris dan penyerahan pada notaris ini ada dua cara, yang pertama bisa diserahkan dalam keadaan terbuka atau bisa juga dalam keadaan tertutup. Kedua cara tersebut mempunyai akibat hukum yang berbeda satu dengan yang lain, yaitu: (a) Testamen diserahkan dalam keadaan terbuka maka harus dibuat suatu akta notaris tentang penyerahan itu dan ditanda-tangani oleh pemberi warisan, para saksi-saksi, serta notaris. Akta penyimpanan khususnya dikaki surat wasiat tersebut, jika

\footnotetext{
${ }^{10}$ Titik Triwulan Tutik, Pengantar Hukum Perdata di Indonesia, (Prestasi Pustaka Publisher 2006).[275].

${ }^{11}$ Effendi Perangin, Hukum Waris, (RajaGrafindo Persada 2018).[78].
} 
tidak ada tempat kosong pada kaki surat wasiat, maka amanat ditulis lagi pada kertas yang lain. (b) Selanjutnya apbila surat wasiat diserahkan kepada notaris dalam keadaan tertutup, maka pemberi warisan harus menuliskan kembali pada sampul dokumen itu bahwasannya surat tersebut berisikan kehendak-kehendak pemberi warisan dan harus menanda-tangani keterangan itu dihadapan pejabat terkait dalam hal ini notaris dan saksisaksi. selanjutnya pewaris harus membuat akta penyimpanan surat wasiat pada kertas yang lainnya.

Testamen yang di simpan pada notaris kekuatannya sama dengan testamen yang dibuat dengan akta umum. Jika pemberi warisan meninggal dunia dan testamen diserahkan kepada notaris dalam keadaan terbuka, maka penetapan dalam testamen itu dapat dilaksanakan karena notaris mengetahui betul isi dari pada testamen tersebut. Berbeda halnya dengan testamen jika diserahkan kepada notaris dalam keadaan tertutup atau tersegel, notaris tidak dapat membaca isinya. Oleh karena itu notaris akan mencatat keterangan yang diberikan oleh pemberi wasiat saat ia menyerahkannya. (2) Surat Wasiat Umum: Merupakan surat wasiat yang dibuat oleh notaris, dengan cara meninggalkan warisan itu menghadap kepada notaris serta menyatakan kehendaknya dan meminta kepada notaris agar dapat dibuatkan akta notaris dengan dihadiri dua orang saksi. Pembuat wasiat harus menyampaikan sendiri kehendaknya itu dihadapan saksi-saksi. Hal tersebut tidak bisa dilakukan dengan menggunakan perantaraan orang lain, baik itu anggota keluarganya ataupun notaris yang bersangkutan. Testamen harus dibuat menggunakan Bahasa yang dipergunakan oleh pewaris ketika akan menyampaikan kehendaknya, dengan memenuhi syarat bahwa notaris dan juga saksi-saksi harus mengerti Bahasa tersebut. Hal ini mengingat kesalahan yang dilakukan dalam surat wasiat, biasanya tidak dapat diperbaiki lagi sebab hal itu baru diketahui setelah pewaris meninggal dunia. Jadi sebisa mungkin kesalahan formalitas itu harus diperkecil. Syarat-syarat untuk saksi dalam surat wasiat umum antara lain sudah harus berumur 21 tahun/sudah menikah, warga negara Indonesia, dan mengerti Bahasa dalam isi surat wasiat tersebut. Adapun sebagai berikut orang-orang yang tidak boleh menjadi saksi adalah: (a) Para ahli waris atau orang yang menirima wasiat, dan sanak keluarga sampai dengan derajat keempat. (b) Anak-anak, cucu-cucu, dan anak-anak menantu, dan anak / cucu notaris. (c) Pelayan-pelayan notaris yang bersangkutan; (3) Wasiat Rahasia: Yaitu surat wasiat yang dituliskan sendiri atau ditulis oleh orang lain yang disuruh oleh pewaris untuk menulis kehendak terakhirnya. Kemudian pewaris menandatangani sendiri surat tersebut. Surat wasiat macam ini harus disegel, kemudian serahkan kepada seorang notaris dengan dihadiri 4 (empat) orang saksi. 
Penutupan dan penyegelan dapat juga dilakukan dihadapan notaris 4 (empat) orang saksi. Selanjutnya pembuat wasiat harus membuat keterangan dihadapan notaris dan saksi-saksi bahwa yang termuat dalam sampul tersebut adalah tulisannya atau orang lain dan ia menanda-tangani. Kemudian notaris membuat keterangan yang isisnya membenarkan keterangan tersebut. Setelah semua formalitas dipenuhi, surat wasiat itu selanjutnya harus disimpan pada notaris dan selanjutnya merupakan kewajiban notaris untuk memberitahukan adanya surat wasiat kepada orang-orang yang berkepentingan, apabila pembuat surat wasiat/pewaris tersebut meninggal dunia.

Wasiat dianggap batal atau tidak sah apabila didalamnya disebutkan penyebab yang memaksa si pewaris untuk memberi sesuatu terhadap seseorang, dan ternyata dikemudian hari terdapat kekeliruan atas penyebab tersebut. Hal ini sesuai dengan Pasal 890 BW. Selanjutnya terkait mengenai paksaan Pasal 893 BW menjelaskan bahwa suatu wasiat/testamen dianggap batal apabila dibuat dibawa ancaman atau penipuan. Dalam dalam keadaan demikian diperlukan pembuktian sejauh mana dianggap terdapatnya unsur paksaan hal ini sesuai dengan ketentuan yang berlaku yaitu dalam Pasal 1324, 1325, dan 1326 BW. Menurut Pasal 1112 BW pembagian suatu harta warisan dapat dibatalkan: (1) Bilamana dilakukan dengan paksaan; (2) Bilamana oleh seseorang atau beberapa orang dilakukan penipuan; (3) Bilamana seorang ahli waris dirugikan dan kerugian ini meliputi seperempat bagian. Kerugian ini bisa disebabkan oleh kekeliruan menaksir harga nilai dari harta benda warisan.

Pasal 874 BW harta peninggalan tiap orang yang meninggal dunia merupakan kepunyaan ahli waris menurut ketentuan perundang-undangan, tetapi pemberi warisan atas surat wasiat dapat menyimpangi dari ketentuan-ketentuan yang termuat dalam Undang-Undang. Untuk itu surat wasiat yang dibuat oleh pemberi warisan, dapat menunjuk seseorang atau beberapa orang menjadi ahli waris selanjutnya disebut erfstelling. ${ }^{12}$ Sedangkan untuk pewarisan berdasarkan ketentuan perundang-undangan ( $a$ b intestato) tercantum didalam Pasal $832 \mathrm{BW}$, yang menjelaskan bahwa:

"Menurut undang-undang yang berhak untuk menjadi ahli waris ialah para keluarga sedarah, baik sah maupun luar kawin dan si suami atau istri yang hidup terlama, semua menurut peratuarn terterah di bawah ini.

Dalam hal bilamana baik keluarga sedarah, maupun si yang hidup terlama diantara suami istri tidak ada, maka segala harta peninggalan si yang meninggal,

${ }^{12}$ H. Zainuddin Ali, Pelaksanaan Hukum Waris di Indonesia, (Sinar Grafika 2010), [92]. 
menjadi milik Negara, yang mana berwajib akan melunasi segala utangnya, sekadar harga harta peninggalan mencukupi untuk itu."

Didalam BW telah diatur mengenai penggolongan para ahli waris dan dibagi dalam 4 (empst) penggolongan yaitu: ${ }^{13}$ (1) Golongan I : Penerima warisan golongan I terdapat dalam Pasal 852 BW, mereka suami atau istri yang hidup terlama serta anak-anak dan seluruh keturunannya; (2) Golongan II : Terdapat dalam Pasal $854 \mathrm{BW}$, yang termsuk ahli waris golongan II mereka orang tua (ayah dan ibu) dan sanak saudara termasuk keturunan saudara-saudaranya; (3) Golongan III : Ahli waris golongan III mereka adalah keluarga dalam garis lurus ke atas sesudah bapak dan ibu. Ahli waris golongan III ini diatur dalam Pasal 853 BW. Tetapi dalam hal pembagian warisan pertama dibagi dua berdasarkan Pasal 850 BW dan Pasal 853 ayat (1) BW: a. 1/2 (satu perdua) bagian ayah; b. 1/2 (satu perdua) bagian ibu. Pembagian ini disebut dengan kloving (pemecahan); (4) Golongan IV : Ahli waris golongan IV adalah mereka yang mempunyai hubungan garis ke samping sampai derajat keenam, diatur dalam Pasal 858 BW yang menjelaskan: jika tidak ada saudara laki-laki dan perempuan, dan tidak ada pula keluarga sedarah dalam salah sat ugaris ke atas, maka setengah bagian dari warisan menjadi bagian sekalian keluarga sedarah dalam garis ke atas yang masih hidup. Setengah bagian lainnya, kecuali dalam Pasal 859 BW menjadi bagian saudara dalam garis yang lain. ${ }^{14}$

Hak dan kewajiban dari penerima warisan testamenter (ahli waris yang menerima warsan berdsasarkan testamen) sama dengan ahli waris a $b$ intstato (ahli waris menurut undang-undang), yaitu memikul aktiva dan pasiva bukan hanya salah satu bagian yang didapat. Untuk dapat menjadi ahli waris, terdapat beberapa syarat: ${ }^{15}$ (1) Orang yang menjadi penerima waris harus mempunyai hak atas harta warisan si pewaris. Hak tersebut dapat timbul karenakan oleh: ${ }^{16}$ (a) Terdapat hubungan darah baik sah atau luar kawin (Pasal 832 BW). Dalam ketentuan Pasal 832 alinea 1 BW disebutkan bahwa penerima waris merupakan para warga (sanak saudara/bloedverwanten) baik keluarga sah maupun diluar kawin dan suami/istri yang hidup paling lama. Dulu ketentuan Pasal 832 BW, janda hanya mewaris jika

${ }^{13}$ Effendi Perangin, Hukum Waris, (RajaGrafindo Persada 2018), [29-33].

${ }^{14}$ Effendi Perangin, Hukum Waris, (RajaGrafindo Persada 2018), [29-33].

15 Sri Hajati, [ et.,al.], Hukum Waris Adat, Islam dan Burgerlijk Wetboek (Airlangga University Press 2018). [223-224].

${ }^{16}$ Sri Hajati, [ et.,al.], Hukum Waris Adat, Islam dan Burgerlijk Wetboek (Airlangga University Press 2018).[223]. 
pemberi waris tidak meninggalkan sanak saudara sampai pada derajat kedua belas. Dengan diundangkannya Staatsblad 1935 No. 486, maka janda dapat mewaris Bersama-sama dengan anak; (b) Pemberian yang melalui surat wasiat diatur dalam Pasal 874 BW. (2) Orang yang menjadi penerima waris harus sudah ada pada saat pemberi waris meninggal dunia (vide: Pasal $836 \mathrm{BW}$ ) dengan perkecualian apa yang tercantum dalam Pasal 2 BW, yang menjelaskan bahwa: "Anak yang ada dalam kandungan seorang perempuan dianggap sebagai telah dilahirkan, bilamana kepentingan si anak menghendakinya. Mati sewaktu dilakihrkan dianggaplah ia tidak pernah telah dilahirkan, bilamana kepentingan si anak menghendakinya. Mati sewaktu dilahirkan dianggaplah ia tidak pernah telah ada." (3) Orang yang menjadi penerima waris tidak termasuk orang yang dinyatakan tidak patut, tidak cakap atau menolak warisan. Orang yang tidak patut untuk mewaris diatur dalam Pasal 838 BW, orang yang tidak cakap untuk mewaris diatur dalam Pasal 912 BW. Sedangkan orang yang tidak menerima warisan atau menolak warisan diatur dalam Pasal 1058 BW. Cakap dan juga patut juga harus dibedakan, cakap termasuk dalam bagian bidang hukum waris testamentair, sedangkan patut termasuk dalam bagian bidang hukum waris menurut undang-undang (tanpa testamen). Tidak cakap maka pembatalannya harus dituntut, sedangkan kalau patut maka hal itu dengan sendirinya batal. Apabila ketidakpatutan lebih luas daripada ketidakcakapan, dengan mengingat ketentuan dalam Pasal 838 BW terdapat salah satu unsur di dalamnya, yaitu "mencoba membunuh" yang tidak diatur dalam Pasal 912 BW. ${ }^{17}$

Testamen yang dibuat oleh pemberi waris dapat juga terjadi penyimpangan terhadap peraturan undang-undang yang ada. Penyimpangan di sini dimaksudkan dengan memberikan bagian untuk orang lain yang bukan merupakan penerima waris yang berhak menerima warisan sebagaiman telah diatur dalam peraturan perundang-undangan (ahli waris ab intestato). Hal ini dikarenakan, Undang-Undang memberikan batasan sebagai bentuk perlindungan hukum bagi penerima warisan yang sebenarnya mempunyai hak atas bagian dari harta kekayaan peninggalan pemberi warisan. Dikarenakan juga dalam waris terdapat pihak yang tidak berhak atas warisan mendapat warisan berdasarkan surat wasiat, hibah, dan hibah wasiat yang melebihi bagian yang harus diterima para ahli waris yang berhak menerima warisan. Untuk penyimpangan yang terjadi dalam hal bagian dari ahli waris diatur dalam Undang-Undang, hal ini tidak dapat

${ }^{17}$ Sri Hajati, [ et.,al.], Hukum Waris Adat, Islam dan Burgerlijk Wetboek (Airlangga University Press 2018). [224]. 
disimpangi seperti telah disebutkan sebelumnya yang dikenal dengan legitieme portie (bagian mutlak). Legitieme portie baru akan bisa dituntut apabila bagian mutlak itu berkurang sebagai akibat dari adanya tindakan si pemberi waris sebelum ia meninggal dunia. Pihak yang memiliki hak atas legitieme portie disebut dengan legitimaris. Pengertian dari Legitieme Portie itu sendiri adalah bagian mutlak yang dapat diberikan kepada penerima warisan ab intestato dalam hal ini memiliki garis lurus ke atas ataupun garis lurus ke bawah (legitimaris) (Hajati, [et.,al.], 2018). Sebagaimana telah termuat dalam BW Pasal 913, yang memberikan definisi mengenai legitieme portie yaitu:

"Bagian mutlak atau legitieme portie, adalah suatu bagian dari harta peninggalan yang harus diberikan kepada para waris dalam garis lurus menurut undang-undang terhadap bagian mana si yang meninggal tak diperbolehkan menetapkan sesuatu baik selaku pemberian antara yang masih hidup, maupun selaku wasiat."

Pihak yang memiliki hak atas legitieme portie hanya bisa menerima aktiva tanpa pasiva dan yang dapat menyerahkan barang tersebut kepada legitimaris adalah pemberi warisan. ${ }^{18}$ Legitimaris yang diberikan warisan harus sesuai dengan penerima warisan berdasarkan ketentuan perundang-undang yaitu dalam hal ini keturunan garis lurus ke bawah ataupun keturunan dengan garis lurus ke atas, dikarenakan terdapat penerima warisan atau ahli waris yang berdasarkan Undang-Undang tetapi dalam hal ini bukan merupakan legitimaris. Bagi penerima warisan yang bukan merupakan legitimaris juga dapat dikesampingkan dengan menggunakan wasiat. Berdasarkan Pasal 920 BW, dijelaskan bahwa legitieme portie harus dapat selalu dituntut, apabila tidak dapat dituntut maka akan menjadi bagian dari ahli waris yang tidak berhak atas warisan (penerima wasiat). Sehigga jika terdapat beberapa legitimaris dan hanya terdapat 1 (satu) orang yang dapat menuntut legitieme portie maka hanya orang yang menuntut tersebut yang akan memperolehnya, sedangkan yang tidak menuntut bagiannya akan jatuh pada penerima wasiat. Dalam Pasal 920 diatur juga mengenai tuntutan atas "bagian mutlak" baru akan dapat dilakukan terhadap hibah atau hibah wasiat yang dapat mengakibatkan berkurangnya bagian mutlak dalam harta peninggalan setelah warisan terbuka. ${ }^{19}$ Selanjutnya dalam hal penuntutan itu juga dapat dilakukan terhadap segala macam bentuk pemberian baik itu berupa erfstelling, hibah, hibah

${ }^{18}$ Sri Hajati, [ et.,al.], Hukum Waris Adat, Islam dan Burgerlijk Wetboek (Airlangga University Press 2018). [296].

${ }^{19}$ Effendi Perangin, Hukum Waris, (RajaGrafindo Persada 2018), [84]. 
wasiat dan atas segala sesuat mengenai pemberian yang dilakukan oleh pe,beri warisan pada waktu ia masih hidup.

Pasal 902 BW mengatur 2 (dua) syarat bagi ahli waris berdasarkan surat wasiat, yang diberikan kepada suami, istri maupun suami atau istri ke dua dan seterusnya yaitu bagian yang didapat tidak boleh melebihi bagian terkecil dari setiap bagian anak sah dari perkwinan pertama dan tidak bisa diberikan lebih dari $1 / 4$ (satu per empat) bagian dari seluruh harta peninggalannya. Kemudian untuk pembagian legitieme portie: (a) Anak kandung diatur berdasarkan Pasal $914 \mathrm{BW}$, yaitu: (1) Seorang anak sah, mendapat bagian sebanyak $1 / 2$ (satu per dua) dari harta peninggalan; (2) Dua orang anak sah, mendapat bagian sebanyak 2/3 (dua per tiga) dari apa yang harus diwaris oleh masing-masing orang dalam pewarisan; (3) Tiga orang ataupun lebih anak sah, mendapat $3 / 4$ (tiga per empat) bagian dari yang dapat diterima, bukan dari harta peninggalan; (b) Untuk keturunan garis lurus ke atas, termuat dalam Pasal $915 \mathrm{BW}$, yaitu: ${ }^{20}$

Untuk ahli waris dalam keturunan garis lurus ke atas (penerima warisan golongan II), maka bagian yang dapat diterima ahli waris golongan II adalah tetap mendapat $1 / 2$ (satu per dua) bagian dari bagian menurut undang-undang menjadi bagian dari masing-masing mereka; (c) Untuk bagian anak luar kawin bagian yang didapat anak luar kawin tetapi harus memenuhi syarat anak tersebut telah diakui dengan sah. Diatur dalam Pasal 916 BW, bagian yang didapat adalah 1/2 (satu per dua) dari tiap bagian yang menurut Undag-Undang harus diwarisinya. Dengan kata lain harus dihubungkan dengan ketentuan yang diatur dalam Pasal $863 \mathrm{BW}$, yaitu anak luar kawin yang mewaris bersama: ${ }^{21}$ (1) Golongan I, mendapat 1/2 (satu per dua) dari bagian menurut Undang-Undang; (2) Golongan II dan Golongan III, mendapat 1/2 (satu per dua) dikalikan 1/2 (satu per dua) bagian dari harta peninggalan; (3) Golongan IV, mendapat $1 / 2$ (satu per dua) dari 3/4 (tiga per empat) bagian dari harta peninggalan.

Pada prinsipnya testamen dapat menyimpangi ketentuan-ketentuan peraturan perundang-undangan, akan tetapi para penerima warisan dalam hal ini legitimaris dalam hal ini penerima warisan dengan garis lurus keatas ataupun ke bawah tidak dapat sama sekali dikesampingkan. Karena menurut ketentuan perundang-undangan mereka ditunjang dengan adanya legitieme Portie (bagian mutlak).

${ }^{20}$ Sri Hajati, [ et.,al.], Hukum Waris Adat, Islam dan Burgerlijk Wetboek (Airlangga University Press 2018). [302].

${ }^{21}$ Effendi Perangin, Hukum Waris, (RajaGrafindo Persada 2018), [304]. 
Adapula hal semacam yang berkaitan dengan legitimaris: ${ }^{22}$ (1) Orang yang bukan legitimaris dapat dikesampingkan dengan adanya wasiat; (2) Bagian multak legitimaris harus perjuangkan. Apabila tidak maka legitieme portie di kesampingkan; (3) Seorang legitimaris mempunyai hak menuntut/melepaskan legitieme portienya tanpa bersama-sama dengan legitimaris lainnya; Penuntutan bagian mutlak baru dapat dilakukan apabila wasiat yang mengakibatkan berkurangnya bagian mutlak dalam suatu harta peninggalan setelah wasiat terbuka (Pasal 920 BW); (4) Pnuntutan itu dapat dilakukan tehradap segala bentuk pemberian yang telah dilakukan oleh si pewaris, baik berupa erfstelling (pengangkatan sebagai ahli waris), hibah wasiat atau terhadap segala pemberian yang dilakukan oleh si pewaris sewaktu si pewaris masih hidup (hibah); (5) Apabila si pewaris mengangkat seorang ahli waris dengan wasiat untuk seluruh harta peninggalannnya, maka bagian ahli waris yang tidak menuntut itu menjadi bagian ahli waris menurut testamen tersebut. ${ }^{23}$

Selain itu ada juga dikenal dengan istilah pembatalan sebagai penerima warisan. Pembatalan penerima warisan dilakukan oleh yang mempunyai harta warisan tersebut dalam hal ini pewaris itu sendiri, yang mana dalam wasiatnya terdapat hal-hal yang mengenyampingkan legitimaris. Tetapi ada juga pengangkatan calon penerima warisan dalam testamen meliputi orang yang tergolong sebagai calon penerima warisan dan dapat juga bagi mereka diluar penerima warisan yang berhak menerima warisan. Pemecatan terhadap legitimaris oleh pewaris diberikan batasan oleh undang-undang guna melindungi hak mutlak dari legitimaris yang harus diterimanya.

Dalam harta warisan juga terdapat pemotongan atau inkorting dimana ini terjadi, apabila bagian dari legitimaris atau hak mutlak yang harus diterimanya terpotong akibat pemberian hibah atau hibah wasiat oleh pewaris. Sehingga hal ini menyebabkan penuntutan terhadap harta warisan untuk dilakukan pemotongan atau inkorting yang bertujuan melindungi hak mutlak dari legitimaris. Diatur dalam pasal 916 huruf a BW. Pemotongan (inkorting) ada dua macam, yaitu: ${ }^{24}$ (1) Pemotongan semu (oneigenlijke inkorting) merupakan pemotongan secara tidak langsung. Hal tersebut dilakukan dari bagian penerima warisan yang tidak berhak atas bagian mutlak dan oemotongan daripada pemberian yang dilakukan dengan testamen. Pemotongan tersebut dibagi menjadi dua bagian, yaitu: (a) Pemotongan

${ }^{22}$ Effendi Perangin, Hukum Waris, (RajaGrafindo Persada 2018), [84].

${ }^{23}$ Effendi Perangin, Hukum Waris, (RajaGrafindo Persada 2018), [84]

${ }^{24}$ Effendi Perangin, Hukum Waris, (RajaGrafindo Persada 2018), [114]. 
secara langsung dari penerima warisan ab intestaso yang bukan legitimaris; (b) Testamen yang sudah dipotong, tetapi belum diberikan karena bagian mutlak tersinggungnm hibah wasiat itu dipotong untuk menutupi kekurangan bagian mutlak; (2) Pemotongan yang semestinya (eigenlijke inkorting) merupakan pemotongan yang benar-benar diadakan, seperti pemotongan terhadap hibah yang telah diberikan dan dikembalikn untuk menutupi Legitieme Portie. Jadi pemotongan yang sebenarnya pada umumnya adalah pemotongan atas hibahhibah atau hadiah-hadiah.

Terkait dengan fokus pembahasan ini yaitu hak mutlak dari pada ahli waris terhadap wasiat/testamen yang menyimpang dari ketentuan legitieme portie terdapat beberapa hal yang kerap kali terjadi, dimana pewaris dalam hal ini sebagai pemilik harta membuat surat wasiat dimana didalam isi surat wasiat tersebut sangatlah bertantangan dengan ketentuan Undang-Undang dari segi pembagiannya. Pewaris sendiri, dalam surat wasiatnya mengenyampingkan legitimaris dan menurut kehendaknya dalam wasiat tersebut ahli waris yang bukan legitimarislah yang mendapatkan suatu bagian porsi yang lebih besar dibandingkan dengan ahli waris legitimaris. Hal demikian tentu sangat bertentangan dengan ketentuan dalam Burgelijk Wetboek (BW) Pasal 913, dalam hal ini Undang-Undang memberi suatu hak mutlak terhadap legitimaris berdasarkan garis lurus keatas maupun kebawah. Juga Undang-Undang memberikan perlindungan terhadap legitimaris agar supaya hak mutlak yang harus mereka dapat sesuai dan tidak mengenyampingkan lagitimaris. Dengan demikian terhadap ahli waris yang bukan legitimaris yang mendapatkan porsi lebih banyak dari legitimaris, haruslah dilakukannya inkorting agar bagian-bagian dari legitimaris bisa terlaksana dan sesuai dengan peraturan yang ada.

\section{PENUTUP}

Kedudukan wasiat yang menyimpangi ketentuan legitieme portie pada hakekatnya bisa, namun dengan batasan-batasan bahwa hak mutlak dari legitimaris haruslah didahulukan dalam pengertiannya, bahwa bagian mutlak dari legitimaris harus diutamakan terlebih dahulu barulah ahli waris berdasarkan wasiat itu bisa memperoleh bagian-bagian mereka. Dan apabila terdapat kelebihan pada bagian ahli waris berdasarkan surat wasiat sedangkan bagian legitimaris tidak sesuai legitieme portie, maka akan dilakukan pengurangan bagian dari ahli waris berdasarkan surat wasiat dengan cara inkorting (pengurangan). 
Adapula keadaan dimana wasiat dapat dijalankan sekalipun menyimpangi dari ketentuan, bilamana: (1) Tidak ada komplain dari legitimaris; (2) Terdapat persetujuan dari ahli waris (dalam pengertian Hibah Wasiat). Jika terdapat komplain dari legitimaris maka Legitieme Portie berlaku atas pembagian warisan tersebut. Selanjutnya menurut hemat penulis, Undang-Undang harus menentukan besaran bagian dari ahli waris yang bukan legitimaris apabila terjadi kasus suatu surat wasiat yang menyimpang dari ketentuan legitieme portie, guna tidak terjadi ketimpangan terhadap pembagian-pembagian para ahli waris tersebut dan menghindari terjadinya sengketa diantara para ahli waris. 


\section{DAFTAR PUSTAKA}

\section{Buku}

Effendi Perangin, Hukum Waris, (RajaGrafindo Persada 2018).

Eman Suparman, Hukum Waris Indonesia dalam Perspektif Islam, Adat, BW, (Refika Aditama 2007).

H. Moh. Muhibbin dan H. Abdul Wahid, Hukum Kewarisan Islam Sebagai Pembaruan Hukum Positif di Indonesia, (Sinar Grafika 2009).

H. Zainuddin Ali, Pelaksanaan Hukum Waris di Indonesia, (Sinar Grafika 2010).

Oemar Salim, Dasar-Dasar Hukum Waris Di Indonesia, (PT. Rineka Cipta 2000).

Sri Hajati, [ et.,al. ], Hukum Waris Adat, Islam dan Burgerlijk Wetboek (Airlangga University Press 2018).

Soerojo Wignjodipoero, Pengantar dan Asas-asas Hukum Adat, (PT. Toko Gunung Agung 1995).

Titik Triwulan Tutik, Pengantar Hukum Perdata di Indonesia, (Prestasi Pustaka Publisher 2006).

\section{Jurnal}

Adam Lukmanto dan Munsharif Abdul Chalim, 'Tinjauan Hukum dan Akibatnya Terhadap Wasiat Tanpa Akta Notaris ditinjau dari Komplikasi Hukum Islam dan Kitab Undang-Undang Hukum Perdata' (2017) 4 Jurnal Akta.

\section{Perundang-undangan}

Al-Qur'an

Burgerlijk Wetboek.

Indische Staatsregeling (I.S.), Staatsblad 1917 Nomor 129, Staatsblad 1924

Nomor 557 tentang Penundukan Diri terhadap Hukum Eropa.

Instruksi Presiden Nomor 1 Tahun 1991 tentang Kompilasi Hukum Islam. 